\title{
Evaluation of the Curriculum of the Teaching in the Multigrade Classrooms Course: Participatory Evaluation Approach
}

\author{
Fatma KARAÇOBAN*, Memet KARAKUŞ \\ Faculty of Education, Çukurova University, Adana, TURKEY
}

\begin{abstract}
This study aims to evaluate a curriculum designed for a course as "Teaching in Multigrade Classrooms" available in pre-service teacher education by using participatory evaluation approach. The case study, one of the qualitative research designs, was used in the study. The participants of the study consisted of the pre-service teachers who studied in Primary School Teaching at a state university in the Eastern Mediterranean region and taking the Teaching in Multigrade Classrooms course, and one of the researchers who implemented the curriculum as well as an observer participating in the implementation process of the relevant curriculum. Observation, interview, and document analysis were used to collect data. The data were inductively and deductively analyzed. As a result, it was decided through this study that the curriculum developed was applicable and could meet the requirements emerging in the context of the current situation, contributing to pre-service teachers personally and professionally.

Keywords: Curriculum evaluation in higher education, Multigrade classroom teaching, participatory evaluation, Teacher education.
\end{abstract}

\section{INTRODUCTION}

Multigrade classrooms refer to education in a single classroom concurrently received by students whose age, grade and skills differ from each other and denote various aspects when compared to independent classrooms (Little, 2005; UNESCO, 1989). Unlike the independent ones, multigrade classrooms exclude homogeneity, and this makes them distinct in terms of teaching methods, duration and how courses are taught. In addition, these multigrade classrooms are often seen in rural areas or places where the population has migrated from their indigenous venues and the birth rate decreases, which render them different from independent classrooms.

Multigrade classrooms, widely exercised in many parts of the world, are preferred in the developing countries because of the paucity of teachers, students, or classrooms as well as inconvenient climatic and residential conditions, whereas developed countries opt for these classrooms owing to the decrease in birth rates, emigration and pedagogical advantages (Little, 1995, 2005; Veenman, 1995; Mason \& Burns, 1997; Little, Pridmore, Bajracharya \& Vithanapathirana, 2005; UNESCO, 1989). Besides, multigrade classrooms still play effective roles because the schools prevent them from getting closed and enable the children living in rural and distant places to access education as a right (Hyry-Beihammer \& Hascher, 2015; Mortazavizadeh, Nili, Isfahani \& Hassani, 2017).

The most important reason for the presence of multigrade classroom is the paucity of the students in rural areas. According to the National Education Statistics Report (The Ministry of National Education [MoNE], 2020) and Education Evaluation Report (EER, 2020), approximately $18 \%$ of the primary schools in Turkey are composed of multigrade classrooms. Even if the rate of the multigrade classrooms seems to be decreasing every passing year, the increasing importance of multigrade classrooms has been re-recognized because of the difficulties experienced in the transported education after 2015. These conditions suggest that as long as villages and hamlets exist, the obligatory practice that education has to be done in multigrade classrooms will be maintained (Erdem, 2015). Today, the decreasing number of students in rural areas due to rural-urban migration causes this practice to be seen mostly in Eastern and Southeastern Anatolian regions. However, it is a fact that multigrade classrooms also exist in other parts of the country. (MoNE, 2005).

When evaluated in terms of the teaching process, multigrade classrooms require teachers to deal with different grade levels concurrently, so courses are mostly carried out in a way that teacher-guided or on-tasks (Little, 2004).

Corresponding Author e-mail: fatmakaracoban@gmail.com https://orcid.org/0000-0001-7779-6500

How to cite this article: KARAÇOBAN F, KARAKUŞ M (2022). Evaluation of the Curriculum of the Teaching in the Multigrade Classrooms Course: Participatory Evaluation Approach. Pegem Journal of Education and Instruction, Vol. 12, No. 1, 2022, 84-99

Source of support: This research was produced from the doctoral thesis within the scope of the project numbered SDK-2015-4970 supported by Çukurova University Scientific Research Projects.

Conflict of interest: None.

DOI: $10.47750 /$ pegegog. 12.01 .09

Received: 29.08.2021

Accepted: 02.11.2021 Publication: 01.01.2022 
When it comes to teaching a new subject, the teacher teaches the lesson to the related group, while the other group has been assigned to do their homework by themselves. (Erdem, 2015). This means that the course durations are halved for teacherguided and on-tasks courses. When examined in the context of the courses, the curriculum of the courses that include more than one discipline such as Life Sciences and Science are studied alternately according to years of education, while courses entailing talent and abilities such as Visual Arts, Music and Physical Education can be taught at different grade levels simultaneously by selecting the most appropriate curriculum in accordance with the students' level (Erdem, 2015; MEB, 2005). In lessons of expression and skills such as Turkish and Mathematics, where the cognitive levels of the students are taken into account, instruction is taught according to their cognitive levels, regardless of the grade level of the student. (Erdem, 2015; MoNE, 2005).

Even if the properties that distinguish multigrade classrooms from the independent ones seem to produce some hardships and make them unjust, they can yield advantages when implemented in an effective manner. This idea is supported in the related literature. Accordingly, it is stated that studying together with students from different age groups and abilities contributes to emotional and social development (responsibility, cooperation, tolerance, patience, being supportive, self-esteem), develops a positive attitude towards school and causes less discipline problems (Jones, 2016; Mason \& Burns, 1997; Miller, 1991; Pavan, 1992; Pratt, 1986; Thomas \& Shaw, 1992; Veenman, 1995). Veenman (1995) analyzed 56 international studies dealing with the cognitive and noncognitive effects of studying with different grade levels and different age groups using meta-analysis method. According to the results of the research, the fact that students of different ages and grades study together does not negatively affect the learning processes of the students. Similarly, $\mathrm{A}^{\circ}$ berg-Bengtsson (2009) investigated multigrade classes in Swedish small schools and emphasized that small rural schools did not provide worse education than other schools ( $\mathrm{A}^{\circ}$ berg-Bengtsson, 2009: 100). When the related literature is evaluated in terms of academic achievement, it is seen that there are studies stating that students studying in multigrade classes are not disadvantaged compared to students studying in independent classes (AbergBengtsson, 2009; Bua \& Martin, 2020; Veenman, 1995).

To be taken as a whole, when multigrade classroom practices are evaluated from the student's point of view, it can be said that it has a positive effect on students' social and emotional development but does not negatively affect their academic development. When evaluated from the teacher's point of view, it is thought that this practice imposes great responsibilities on the teacher in the "planning, implementation and evaluation of teaching" phase. As a matter of fact, studies in the literature emphasize that teachers working in multigrade classes take more responsibility than teachers working in independent classes (Hyry-Beihammer \& Hascher, 2015; Little, 2001; Mulyran-Kyne, 2007; Oral \& McGivney, 2014; Sağ \& Sezer, 2012). The successful continuation of such practices seems to be directly related to teacher qualifications. When the studies conducted with teachers working in multi-grade schools are examined, it is seen that the teachers find the pre-service training they receive inadequate and dysfunctional in terms of "multiplexed classroom practices" (Adepoju, 2009; Bulm \& Diwan, 2007; Cornish, 2006; Jakobson, 2007; Kamel, 2012; Mulryan). -Kyne, 2007; Thephavongsa, 2018; UNESCO, 2013; Vithanapathirana, 2005). However, considering the diversity of students and learning objectives, there is a greater need for teachers who can professionally cope with the difficulties of multigrade classroom practices (Hyry-Beihammer \& Hascher, 2015). When pre-service teacher education is considered globally, it is seen that there is usually no focus on special education for rural schools (Arriaga \& Ruiz-Gallardo, 2017; Raso, Hinojo \& Solá, 2015). It is stated that addressing this issue only in program implementations or in teaching courses does not bring solutions to current educational problems and difficulties (Boix, 2020).

In Turkey, on the other hand, teacher training for multigrade classroom schools is provided with the Teaching in Multigrade Classrooms course in the Primary School Teaching undergraduate program. The course is a two-hour and two-credit theoretical course taking place in the last term of pre-service teacher education program. The content of the course is defined by the Council of Higher Education (TCHE) as "the concept of multigrade classroom, the importance of education in multigrade classrooms; reasons that require multigrade classrooms, structure of the curriculum in multigrade classrooms, classroom management in multigrade classrooms, planning and evaluation of the learning-teaching process in multigrade classrooms" (TCHE, 2007: 39).

Many studies in national and international literature have emphasized that multigrade classroom practices are not sufficiently represented in teacher education, thus preservice teacher education is insufficient in this sense (Arriaga \& Ruiz-Gallardo, 2017; Buaraphan, Inrit \& Kochasila, 2018; Hardman, Stoff, Aung \& Elliott, 2014; Hyry-Beihammer \& Hascher, 2015; Kline, White \& Lock, 2013; Korthagen, 2010; Sağ, 2011). Some studies also show that pre-service teachers hold their degrees without having direct experience with regard to multigrade classrooms, which causes them to lack certain skills in multigrade classroom education (Sağ, 2010; National Teacher Strategic Document [NTSD], 2011; Wenger \& Dinsmore, 2005).

Teachers newly assigned to schools with multigrade classrooms experience more hardships than those appointed to schools with independent classrooms (Little, 2001; Oral \& McGivney, 2014; Mulyran-Kyne, 2007). This is because 
multigrade classroom practices require a different approach from epistemologically and methodologically independent classroom practices. This means that teachers take on different duties and roles. (Boix, 2014; Chaparro-Aguado \& Rubio, 2010; Cornish, 2006). The fact that multigrade classrooms function more differently than independent classroom causes teachers to take more responsibility in planning, implementing and evaluating teaching, classroom management, and dealing with student interests and needs (Hyry-Beihammer \& Hascher, 2015; Mulryan-Kyne, 2007).

However, it is emphasized in the literature that there is a general lack of guidance regarding how the core curriculum can be adapted to multigrade teaching for different learners. This challenges teacher education institutions to develop more professional training programs for preservice and in-service teachers in the area of multigrade teaching (Hyry-Beihammer \& Hascher, 2015). Raising awareness about the potential and effectiveness of multigrade classroom practices and developing this in programs are among the aims of teacher education (Murlyan-Kyne, 2007). Suwanrat (2012) states that teachers who participated in training related to teaching in multigrade classrooms have acquired both internal and external supervision to successfully continue the education and training services realized in these schools. The points mentioned, increase the importance of the lessons related to multi-level teaching in pre-service teacher education. When the points mentioned in the literature are evaluated as a whole, it becomes necessary to examine the relevant courses in the program in order to increase the quality of both teaching practices in multigrade classes and pre-service teacher education. Therefore, it is aimed in this study to evaluate the Curriculum for "Teaching in Multigrade Classrooms" course in the Primary School Teaching program with a participatory evaluation approach.

\section{Why has Participatory Evaluation Approach been used?}

Participatory Evaluation (PE), one of the curriculum evaluation approaches, is expressed as the descriptor of collaborative work (Cousins \& Whitmore, 1998). Stake (1976) notes that the "primary stakeholders" are real curriculum participants and that the evaluation process with primary stakeholders provides a more in-depth engagement (Garaway, 1995). Burke (1998:44) defines participatory evaluation as "a series of principles and the process of participating in evaluation efforts" and states these principles as follows:

- The evaluation must involve and work for the program's end users, the key stakeholders.

- The evaluation must be context-specific, and rooted in the concerns, interests, and rind problems of the program's end users. Appropriateness within a given context is fundamental to the effectiveness of the evaluation exercise and ensures that the results will be useful to program stakeholders.

- Participatory Evaluation approach uses and reflects the experience and knowledge of key stakeholders, unlike traditional evaluation approaches.

- The evaluation is not and cannot be irrelevant. Participatory evaluation is generally quite relevant to contexts, stakeholders, processes and outcomes. It influences and is influenced in some way.

- The evaluation favors collective methods of knowledge generation. Participatory evaluation is the process of collective reflection and planning.

- The evaluator (facilitator) shares power with the stakeholders and should be aware of their talents.

- In participatory evaluation, the evaluator explains his / her attitudes, ideas and behaviors in a continuous and questioning manner.

Burke (1998) emphasizes that there is no formula while evaluating the curriculum. However, there are important points where some important decisions were made. These points are stated as follows (Burke, 1998: 47):

- B1-Deciding to do it: What do we want to learn? What conditions will we consider? Does the model serve our purpose?

- B2-Assembling the team: Who will take part in the evaluation? Internal evaluator or external evaluator or both? What should the evaluator's skills and abilities be?

- B3-Making a plan: Stakeholders are directed to participatory evaluation. The agenda is set (Have we finalized the goals and objectives? Who wants to know what and why?).

- B4-Collecting the data: Who will collect the data? By what methods will data be collected?

- B5- Synthesizing, analyzing, verifying the data: Various data sets are created and analyzed, and participant confirmation is obtained.

- B6- Developing action plans for the future: Action plans are created so that the information obtained can be used in future studies.

- B7- Controlling and using outcomes and reports: How do we want to use the results? How should we prepare the report?

Considering the points stated by Burke, it is seen that the evaluation process starts with the decision-making step, and then includes the steps of selecting stakeholders that will contribute to the process, planning the evaluation, determining data collection tools, collecting data, which is to be analyzed, evaluated and finally reported.

Curriculum development and evaluation studies are a continuous process that complements each other cyclically and requires the participation of many stakeholders. The participation of stakeholders is regarded as crucial in evaluation studies for the development of curricula as they 
provide more information specific to the process and context (Burke, 1998). For Burke (1998), in order for the participatory evaluation process to be successful, what should be prioritized are not only outcomes and recommendations but also the stakeholders' knowledge and experiences in the process.

Multigrade classroom practices are special in nature and, as mentioned before, differ in many ways from the independent classroom applications common throughout the country (Erdem, 2015; Berry \& Little, 2006). This differentiation makes it important and functional to use approaches that take into account more in-depth and context-specific knowledge as well as experiences in practices carried out for multigrade classroom practices in teacher education. For this reason, in this study, it was decided to use the participatory evaluation approach, taking into account the principles stated by Burke and the points he emphasized. Accordingly, answers to the following research questions were sought:

- What are the views of the participants on the components of the curriculum developed?

- What are the views of the participants on the individual and professional contributions of the curriculum, the factors that make teaching difficult and that enhance the process?

- To what extent were the needs determined in the needs analysis study met during the implementation process?

\section{Method}

\section{Research Design}

This research includes only the evaluation aspect of the curriculum development, implementation, and evaluation study for the Multigrade Classrooms course. The evaluation study was based on case study and the embedded single-case design was used (Yin, 2003). This design often contains more than one substrate or unit in a single case. This requires the inclusion of more than one analysis unit (Yıldırım \& Şimşek, 2013). Accordingly, the research design integrated with the curriculum evaluation process is shown in Figure 1.

\section{A. Planning and implementing the curriculum.}

The planning and implementation of the curriculum is not the subject of this study. However, it is briefly explained to give information about how the evaluated curriculum was developed and implemented. At the stage of planning the curriculum of the Teaching in the Multigrade Classrooms course, a needs analysis study was carried out first. The needs analysis study was performed through semi-structured interviews with the teachers working in the multigrade classrooms, education inspectors who inspected schools with multigrade classrooms at least once, students studying in multigrade classrooms and their parents, and pre-service teachers who successfully completed Multigrade teaching course. The needs analysis

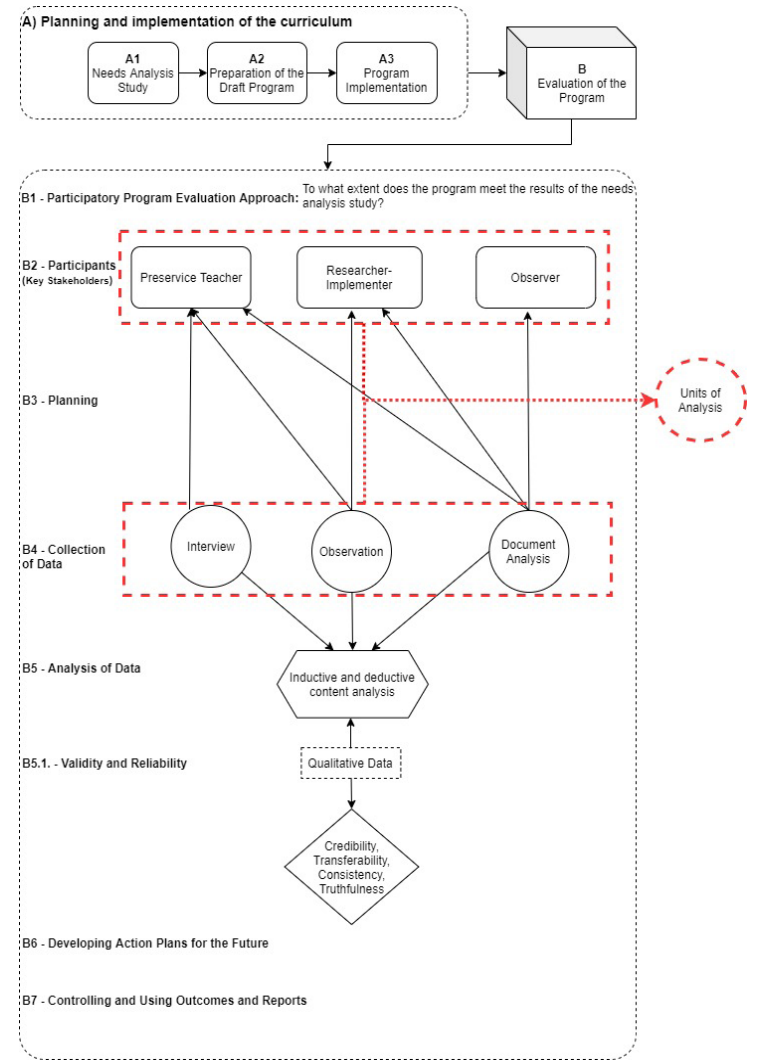

Fig. 1: Research Design Integrated with the Curriculum Evaluation Process.

study, involving 25 participants in total, included the problems discussed in the national and international literature with respects to the multigrade classroom practices as well as the points needed in pre-service teacher education, and the study results were summarized in Figure 2, taking into account the components of the curriculum.

Considering the results given in Figure 2, the tentative curriculum was prepared in accordance with the linear content arrangement approach. Action research was taken as a basis in the implementation of the tentative curriculum. Accordingly, the subjects were divided into weeks according to their content in a process covering a total of 14 weeks and 28 course hours, where each theme constituted an action cycle. Six lesson hours (1st cycle) including "Multigrade Classroom Characteristics" in the first, second and third weeks; six lesson hours (2nd cycle) in the fourth, fifth and sixth weeks, including the subjects of "School-Family and Local Community Cooperation and School Management in Multigrade Classrooms"; in the seventh, eighth and ninth weeks, six lesson hours (3rd cycle), including the subjects related to the "Planning and Observation in Multigrade Classrooms" process were planned. The fourth action cycle was the "Implementation and Evaluation" process, which corresponded to the 10th, 11th, 12th, 13th and 14th weeks and consisted of 10 lesson hours in total. 


\section{B. Evaluation of the Curriculum}

\section{B1. Participatory Evaluation Approach (Deciding to do it):}

Upon deciding on the purpose of evaluation, it was evaluated which conditions to take into consideration and accordingly, whether or not the model would serve our purpose. In this study, where the participatory curriculum evaluation model was used, it was aimed that all stakeholders, especially the practitioners and the target group, took active roles in the development and implementation of the evaluation (Zukoski \& Luluquisen, 2002). Within this process, the development of both the participants and the curriculum was supported through the consideration of the interests and needs of the participants (Burke, 1998).

\section{B2. Participants (Assembling the team):}

Participants of the study consist of pre-service teachers studying at a state university in the Eastern Mediterranean region, a researcher-practitioner from this university and a subject matter expert as observer. Information related to the participants is presented in Figure 3.

As indicated in Figure 3, 34 pre-service teachers participating in the study were determined by appropriate sampling method among the pre-service teachers who took the Teaching in Multigrade Classrooms course at the university where the study was conducted. A criterion sampling was used in this study while selecting the pre-service teachers, and the observer. The criteria employed for the selection of pre-service teachers who were recruited in this study included a voluntary principle, pre-service teachers' academic success and the level of participation in the course. General academic average is taken into account for academic success. For the level of participation in the course, the frequency of voluntary participation of pre-service teachers in activities and lectures was observed. Gender was not determined as a criterion, the equal distribution of pre-service teachers according to gender occurred by chance. In the selection of the observer to be recruited, together with the principle of volunteering, it was taken into account whether they had a master's or doctorate degree in the domain of Curriculum and Instruction and if they had carried out studies on curriculum evaluation.

\section{B3. Planning (Making a plan):}

In the context of the research, the areas to which stakeholders were anticipated to contribute were clarified and it was planned which data would be collected from whom, how, when and how often, as well as the way it would be analyzed and reported. It was also aimed to investigate the features and elements of the developed curriculum in detail. Accordingly, the points stated in the related literature were taken into consideration in the evaluation of the effectiveness and applicability of the curriculum. As and "whether the curriculum meets the requirements arising from the needs analysis study and whether it is applicable or not" is among the priority criteria. Accordingly, in the evaluation of the curriculum, it was intended to determine the opinions about the components of the curriculum (objectives, content, teaching-learning process, measurement-evaluation). McCain (2005) and Sanders and Nafgizer (1976) viewed evaluation as determining the strengths and weaknesses of the curriculum, problems encountered, solutions and needs. In this regard, another criterion considered within the scope of the study was "to focus on the difficulties and suggestions in the implementation process". Oliva (2005) emphasized the educational dimension of curriculum evaluation and stated that evaluation includes all variables related to school. In this context, the last criterion addressed during the evaluation phase was determined as "individual and professional contributions of the curriculum, factors making teaching difficult and suggestions".

\section{B4. Data Collection (Collecting the data):}

A systematic process was followed in collecting the data. Unstructured observation, semi-structured interview

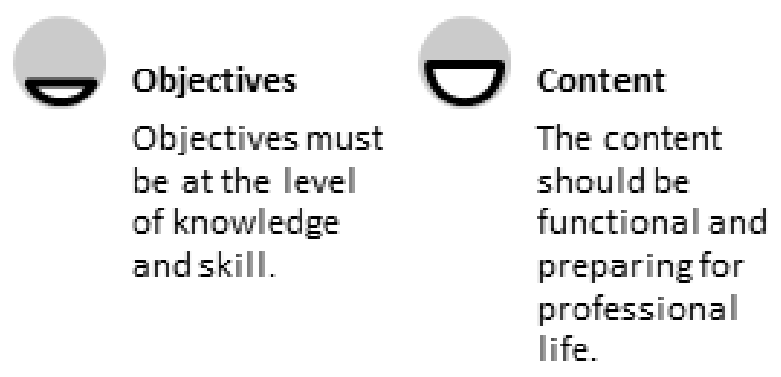

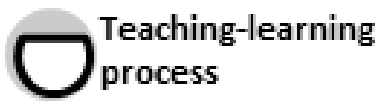

It should be centered on student interests, needs and desires, enabling authentic learning experiences, facilitating the understanding of information, and providing active participation.

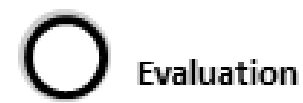

Evaluation should ensure the permanence of the information. Measurement tools should provide content validity.

Fig. 2:. The Results Regarding the Components of the Curriculum Which Have Been Obtained through the Needs Analysis conducted for the Curriculum Development Study. 
and document review techniques were used to obtain the data.

\section{Observation:}

Observation was used to obtain detailed and comprehensive data on the implementation process of the curriculum. Thus, it was ensured that the behaviors of the participants were explained in a holistic understanding and within their own context (Yıldırım \& Şimşek, 2013). This situation also allows the researcher to observe the behavior directly and in its natural context. The observations made in unstructured and natural context included 28 lesson hours. Recordings were obtained using a video camera. Thus, it was provided the opportunity to carry out long-term analysis over time (Bailey, 1982).

\section{Interview:}

Interview data were obtained from pre-service teachers through semi-structured interview forms conducted in two different time periods. The forms were created by the researchers and used after they were submitted to expert review. Accordingly, the first interviews were held at the appropriate time after the completion of 12 class hours, and the last interviews were held at the appropriate time after the implementation and evaluation process of the course was completed. Information on the interview form and data collection is presented in Figure 4

\section{Document Analysis:}

The document analysis included reflective evaluation forms, observer evaluation notes and researcher diaries. Information on the forms is summarized in Figure 5.

\section{B5. Data Analysis (Synthesizing, analyzing, verifying the data):}

Inductive and deductive content analysis methods were used to analyze the data collected through interviews, observations, and document analysis. In the deductive content analysis, the purpose (achievement), content, educational conditions (learning-teaching process) and the measurement-evaluation process were taken into account (Demirel, 2013). The fact that the same categories were used in the needs analysis study made it easy to determine whether the curriculum served the purpose or not. NVIVO 10 program was used in the analysis of the data.
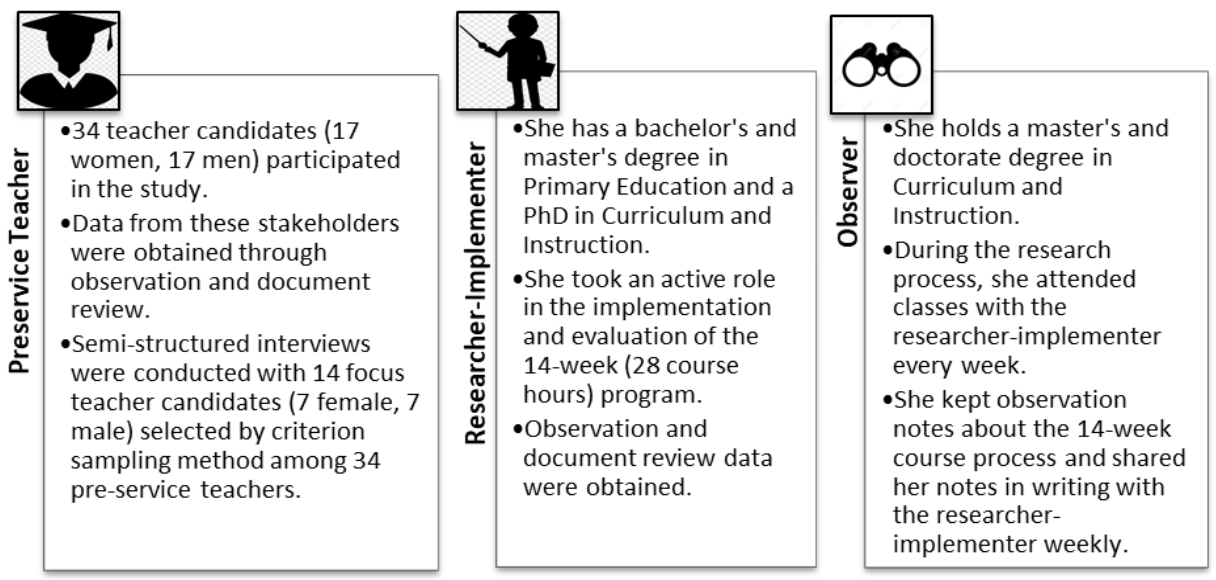

Figure 3. Demographic Information of The Participants.

\begin{tabular}{|c|c|}
\hline Mid-Process Interview & Post Process Interviews \\
\hline $\begin{array}{l}\text {-It was carried out with the focus pre-service } \\
\text { teachers. }\end{array}$ & $\begin{array}{l}\text {-It was carried out with the focus pre-service } \\
\text { teachers. }\end{array}$ \\
\hline $\begin{array}{l}\text {-It was conducted in order to get participants' views } \\
\text { on the curriculum and the functioning of the } \\
\text { teaching process. }\end{array}$ & $\begin{array}{l}\text { - It was conducted in order to get the opinions of the } \\
\text { participants about the whole curriculum and the } \\
\text { entire teaching process. }\end{array}$ \\
\hline $\begin{array}{l}\text { - In the interview form, questions about the lesson, } \\
\text { the teaching process, the classroom environment } \\
\text { and the elements of the curriculum were included. }\end{array}$ & $\begin{array}{l}\text { - In the interview form, the questions about the } \\
\text { elements of the curriculum were asked in detail, and } \\
\text { the questions about the academic and individual } \\
\text { contributions of the course were also included. }\end{array}$ \\
\hline
\end{tabular}

Figure 4. Interview Form and Data Collection Process 


\section{B5.1-Validity and Reliability Studies}

Validity and reliability studies carried out through qualitative techniques are done considering credibility, transferability, consistency and confirmation analysis (Creswell, 2016; Merriam, 2013; Patton, 2014; Yıldırım \& Şimşek, 2013). Accordingly, the procedures regarding validity and reliability are summarized in Figure 6.

As indicated in Figure 6, coder reliability has been calculated in order to ensure consistency. So that it could be achieved, an expert with a doctorate degree in Curriculum and Instruction and working in the Department of Primary School Teaching was included in the study as a second coder. It was concluded that the reliability coefficients calculated between two coders on the same data set were .71 for the researcher's diary, .81 for the interview, .89 for the observer evaluation form, and .73 for the observation records. Miles and Huberman (1994) state that for 95\% of the codes, there should be an $80 \%$ level of agreement. Landis and Koch (1977), on the other hand, accepted that if the reliability coefficients less than 0 as no agreement, between 0 and 0.20 as slight, $0.21-$ 0.40 as fair, $0.41-0.60$ as moderate, $0.61-0.80$ as substantial, and $0.81-1$ as nearly perfect agreement. Yıldırım and Şimşek (2013) consider 0.70 and above acceptable. O'Connur and Joffe (2020) emphasize that all these levels are random and that the researcher should decide for which level is acceptable, taking into account the purpose of the study. Considering the levels and acceptances stated in the literature, it was decided that the reliability coefficients obtained in this study were acceptable.

\section{FINDINGS}

Findings were categorized according to the components of the curriculum, its strengths and weaknesses, recommendations regarding the curriculum, and whether it meets the requirements revealed in the needs analysis, as stated in B3-Planning. Accordingly, the categories and subcategories obtained are presented in Figure 7.

The categories and subcategories in Figure 7 are explained under sub-headings.
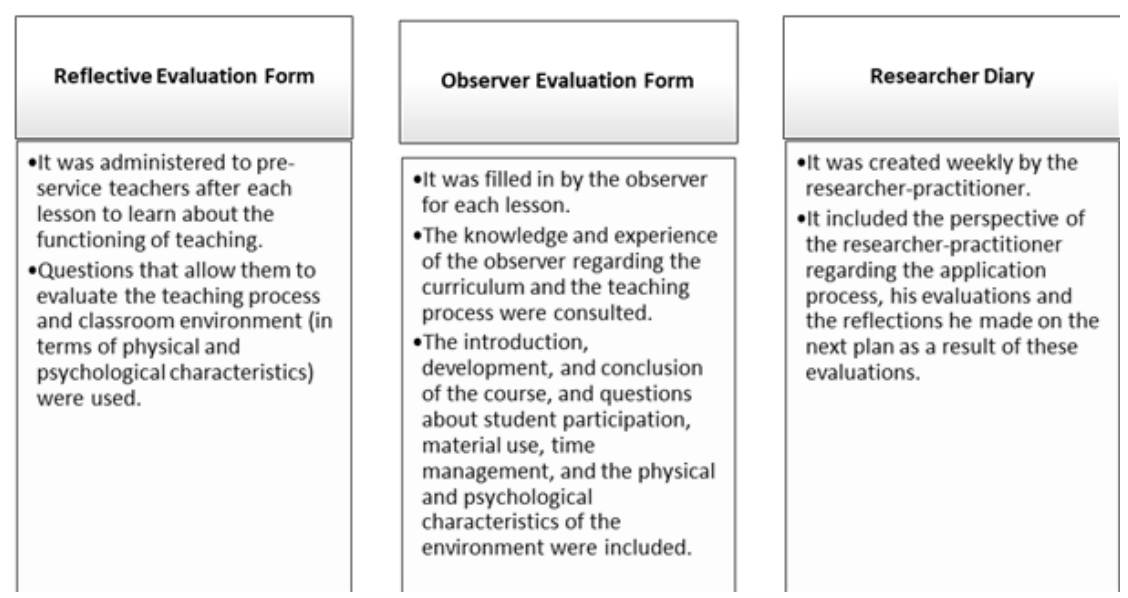

Fig. 5. Data Collection Tools and Characteristics in the Document Analysis
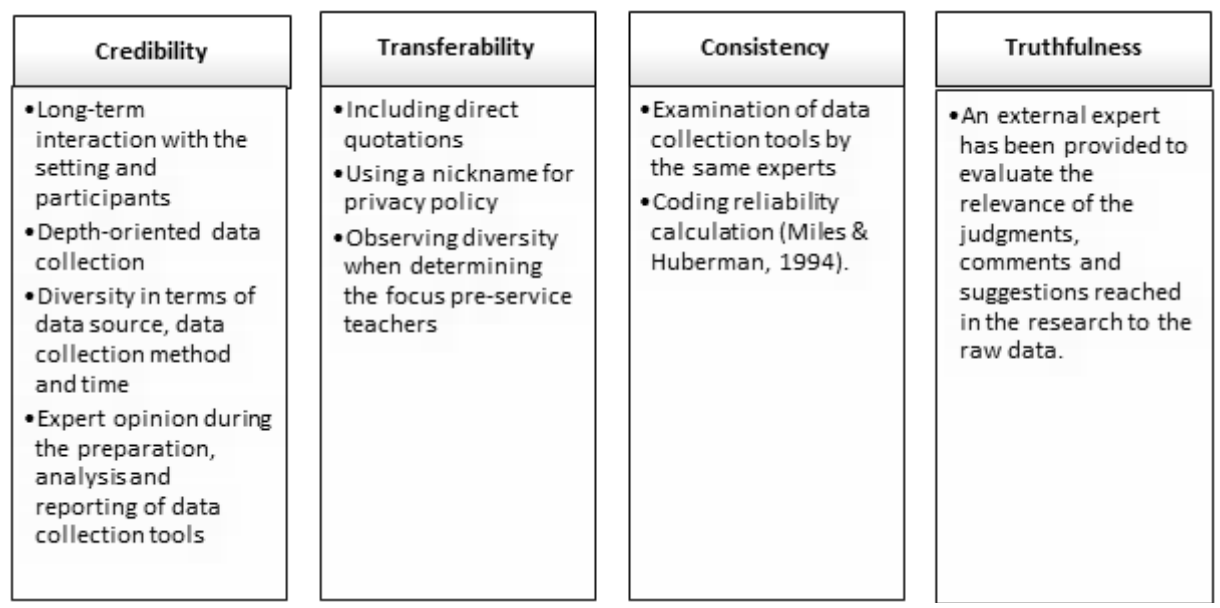

Fig. 6: Information Regarding Reliability and Validity for Qualitative Data 


\section{Findings regarding Components of the Curriculum Objectives}

When the data were analyzed considering objectives, it was found that the pre-service teachers understood the importance of the course and acquired the skill of evaluating the course. Asli, one of the pre-service teachers, interpreted this situation in the last interview as follows:

We learned a lot academically and theoretically in terms of education in multigrade classrooms. Apart from that, as I said, experience was more important to me than academic knowledge. So what I remember is that there were so many things we could experience through which we could improve new skills. The forms we used in the course were very efficient in learning the information of the courses (term-end interview, Asli, p. 6).

The researcher-practitioner stated her observation on this issue in the diary dated May 9, 2016, as follows:

Another point that made me feel good during the course was that the interest shown by the pre-service teachers in the feedback I provided and the change in their selfconfidence as a result of their experience in a school with a multigrade classroom. It was as if the balloons of concern they had carried over their heads since the beginning of the period had collapsed one by one. They were given a great opportunity to improve their teaching skills. They gained experience by putting the theoretical knowledge they had about how to teach the courses where the teachers teach, and homework is done by the students concurrently into practice (Researcher Diary, 9 May 2016).

It was determined that this situation, which was stated at different times by the pre-service teachers and the researcherpractitioner, was also emphasized by the observer. The observer expressed his opinion on this issue as follows:

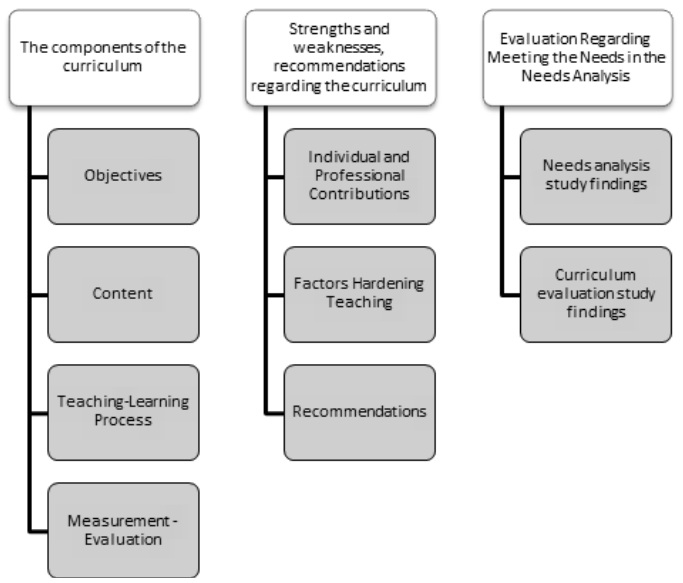

Fig. 7: The Categories Obtained in Line with the Research Questions
I think that the dimension in which the station technique was applied both provided student participation and contributed to the achievements of students at the level of understanding and skill (Observer Evaluation Notes, 14 March 2016).

\section{Content}

When the data on the evaluation of the curriculum were analyzed by considering the content item, the resulting codes indicated that the content was "sufficient" (f: 25$)$ and "prepared for professional life" (f: 22). The pre-service teachers Aydın, who found the content sufficient, expressed this opinion in the interim interview as follows:

I think the subjects were sufficient theoretically. I think how much we can apply this in practice now depends upon us... I think it went well theoretically (Interview, Aydin, p. 3).

In the lecture dated May 9, 2016, Berke, the pre-service teachers, noted as follows that that the content was prepared for professional life:

I think what we experienced was not just about multigrade classrooms but more than that. In other words, it enabled us to be more careful in the way of preparing a plan, which will be very useful in regular teaching, or in terms of planning steps or preparing a better classroom environment for students (Observation, Berke, 09 May 2016).

\section{Teaching-Learning Process}

When the data gathered within this study was analyzed in terms of the teaching- learning process, it was found that the participants mostly expressed their opinions about this component of the curriculum. The categories and subcategories that emerged regarding the teaching- learning process is presented in Figure 8.

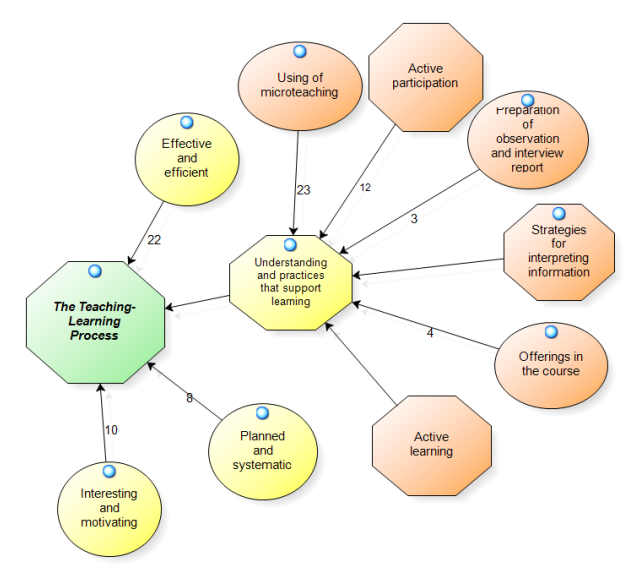

Fig. 8: Categories and Subcategories Regarding the Teaching-Learning Process 
As shown in Figure 8, the subcategories related to the teachinglearning process are directed towards the functioning and quality of the process. In these findings, which emerged in line with the data obtained, it was concluded that the participants found the process effective and efficient (f: 22), planned and systematic (f: 8), and also interesting and motivating (f: 10). The pre-service teacher Ebru, who found the process effective and efficient, expressed her opinion in the general evaluation made in the last lesson of the term as follows:

We were never introduced to classes of this kind where we were that motivated with high numbers of practices and took part attentively (Observation, Ebru, 9 May 2016).

The evaluation notes from the observer also support this view:

I can say that the information given for the general structure of the course was sufficient, satisfactory and intelligible for students (Observer Evaluation Notes, February 15, 2016).

Another category that emerged in the teaching-learning process was about "the understanding and practices that support learning". Under this category, participants should be able to use micro-teaching technique (f: 23), employ insights and practices that support active participation in the process (f: 12), benefit from knowledge interpretation strategies, increase motivation with the offerings in the course (f: 4), and develop an attitude that support active learning. The findings also showed that they found it useful to incorporate the practices within a report prepared after observations and interviews (f: 3). The pre-service teacher, Azra, conveyed her opinion on the use of micro teaching technique in the term-end interview as follows:

The contribution of micro teaching to learning is that it enabled us to witness the shortcomings made and made a great contribution as it helped us compensate for those shortcomings in the next week. Most people, including myself, have watched the videos attentively. I think it was quite effective. (Term-end meeting, Azra, p.4).

The data obtained from elaboration strategies are mostly based on course observations. In this context, the most repetitive point was presenting guiding questions and explanations (f: 63). This situation took place in the lesson on February 15, 2016, as follows:

A-U: The teacher said something like this, there was a new student named Canan who came to the class, when she realized that Canan was new, she said "Nedret, you take care of her too," Did you notice? What do you think she tried to do?

Barış: Peer teaching

A-U: Yes, there was an emphasis on peer teaching... The teacher can assign literate students as guides or responsible teachers and use them as an aid in teaching reading and writing (Observation, 15 February 2016).
When the sub-categories emerging in the active learning category were examined, it was found that these were guiding learning (f: 17), adopting a student-centered approach (f:17), whole and permanent learning (f: 15) and presenting authentic learning experiences (f:12). As is in the following, the observer stated their opinion about guiding learning and taking a student-centered approach as a basis:

I assume that the case analysis used in the teaching-learning process has been successful in the efficient teaching of the course, adopting a student-centered approach and guiding the student to thinking and questioning (Observer Evaluation Notes, February 22, 2016).

\section{Measurement - Evaluation}

Another element considered in this study, where the curriculum was evaluated, was the measurement-evaluation process. The subcategories of "taking into account basic principles" and "diversity in tools and approaches" emerging under this category are given in Figure 9.

As shown in Figure 9, regarding the basic principles, it was stated that the assessment and evaluation process was compatible with the learning outcomes (f: 5), high in content validity (f: 6 ), having sufficient duration (f: 3 ), supporting individual development (f: 3 ) and targeted to developing thinking skills (f: 2). The pre-service teacher, Bora, expressed his opinion about the content validity in the interview held at the end of the term as follows:

A-U: Well, what can you say about what was done within the scope of assessment and evaluation activities in the course? What do you think?

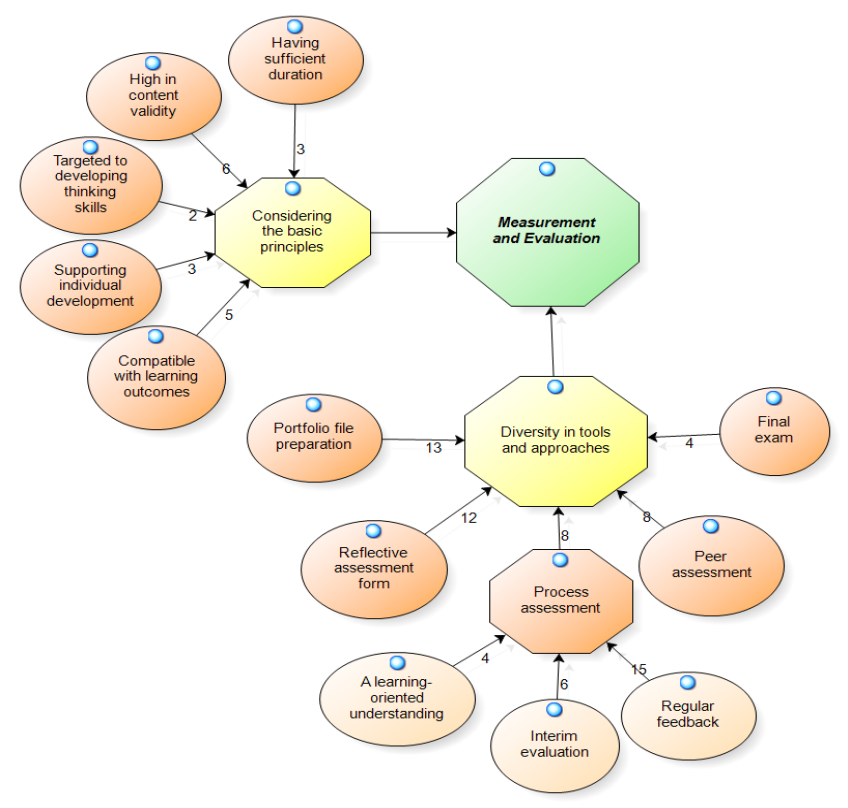

Fig. 9: Category and Subcategories regarding Measurement - Evaluation 
Bora: From the beginning of the year, in other words, if we think about it from the beginning of the course, it has been serving all we have done. There was nothing we did not study. We studied and practiced them all. There was nothing in the exams or evaluation forms unfamiliar to us. It included all of them, the questions were okay, very clear and understandable (Term-end interview, Bora, p. 4).

The points emerging in the diversity category in assessment and evaluation tools and approaches are portfolio file preparation (f: 13), reflective assessment form (f: 12), peer assessment (f: 8), process assessment (f: 8 ), and final exam (f: 4). Thinking that preparing a portfolio file is effective, Erol mentioned the contribution of this file to learning in the term-end interview with the following utterances:

Now, we have a resource. In the previous years, our teachers usually told us to do the things without giving us clear instructions or guidance, thus we always learned what to do from our friends. They were also not able to do well, hence we frequently got confused, and the result was never satisfying. In our classes with you, on the other hand, we were provided a resource. It worked, so we went over it and noticed our shortcomings. When we were preparing something, for example a plan, we browsed there to see if there was something missing here; we prepared that plan accordingly, that is, it was good (Term-end interview, Erol, p. 4).

\section{Strengths and Weaknesses, Recommendations Regarding the Curriculum}

When the data analysis was carried out, it was found that the curriculum contributed personally and professionally to

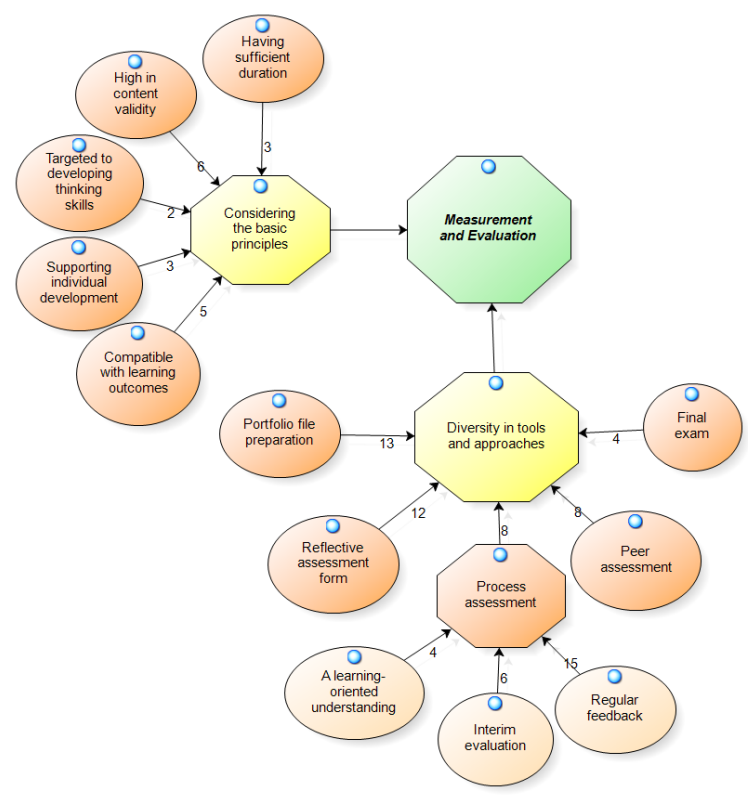

Fig. 9: Category and Subcategories regarding Measurement - Evaluation. the pre-service teachers. In addition, some points that make teaching and learning difficult and some suggestions for the improvement of the curriculum were also addressed. These findings are presented in Figure 10.

Figure 10 shows that pre-service teachers refer to personal and professional contributions such as professional awareness (f: 14), self-confidence (f: 9), and motivation (F: 5). In addition, it was observed that there were pre-service teachers who noticed their personal development (f: 6) and stated that their peer relationships improved (f: 4). Expressing that he gained professional awareness in the process, Baybars conveyed this view in the lecture dated May 9, 2016, as follows:

Dear Teacher, if you had not paid attention to the practice and pointed to the importance of what you instructed, we could have been like the child we watched (Two Languages One Suitcase, Emre Teacher). So at least now I can't say I'm that competent, but at least I know what to do and what I might be faced with. Previously, we didn't even know how to do homework in the class with the students as teachers. Actually, I was angry, when it was reported to me about this three-day village and school practicum, I went crazy anyway. But then I realized how good it was. We learned a lot when we got into it, that is, we experienced the things that took place in the course (Observation, Baybars, 9 May 2016).

With respect to the factors that harden teaching and learning for the pre-service teachers, the most challenging ones appeared to be the "long-lasting final exam" (f: 4) and the "course taking place in the eighth semester" (f: 4 ). In addition to this, it was reported that they had difficulties due to the assignment of group homework, doing the lesson just before the mealtime, spending the whole time on the lesson without a break for some weeks and having to do homework.

When the recommendations regarding the improvement of the curriculum were considered, the participants mostly reported that the course should not be given in the last term (f: 10). In addition to this, they stated that "the number of practices should be increased" (f: 5), "the course should be taught in the same way in the following years" (f: 5 ), "it should be done in different multigrade schools" (f: 2), "its place in the weekly course schedule should be changed "(f: 2 )," micro teaching practice could be done in the classroom itself as well"(f: 1$)$ and " more lesson plans should be prepared "(f: 1 ). Damla states that multigrade teaching course should be taught in a similar manner and expresses her ideas as follows:

I would rather the next generation to study in education faculties receiving multigrade teaching course in a similar way in which we are studying now because this is indeed crucial, maybe the most fundamental. It is odd to learn this but not to implement it. To be honest, I would like this course to be taught this way in the following years (Term-end interview, Damla, p.5). 
During the implementation of the curriculum, reflective evaluation forms were distributed to the pre-service teachers after each lesson, and they were asked to reflect their views on how the course was taught as well as the physical and psychological characteristics of the classroom setting. Findings regarding the development of the process are presented in Figure 11.

Given the cyclical process in Figure 11, it was reported that the hardships of the pre-service teachers during the implementation of the curriculum and their suggestions to make learning more permanent decreased over time. This situation suggests that the problems arising from the implementation process of the curriculum have been largely solved.

\section{Evaluation Regarding Meeting the Needs in the Needs Analysis}

The needs arising in the needs analysis study and the findings at the end of the curriculum evaluation study are compared in Table 1.

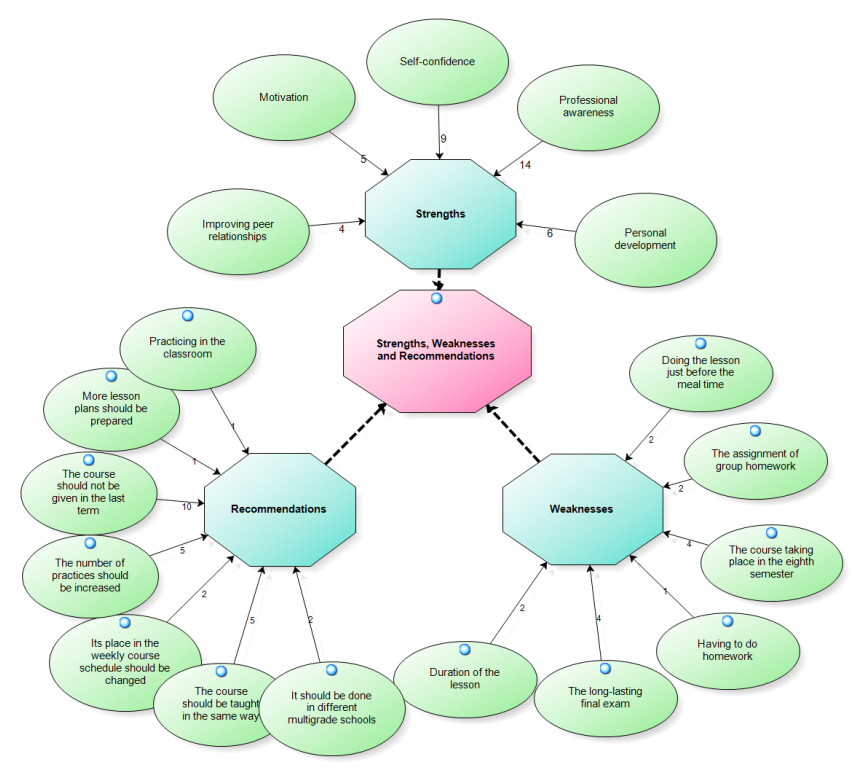

Fig. 10: Categories and Subcategories Related to Strengths, Weaknesses, and Recommendations

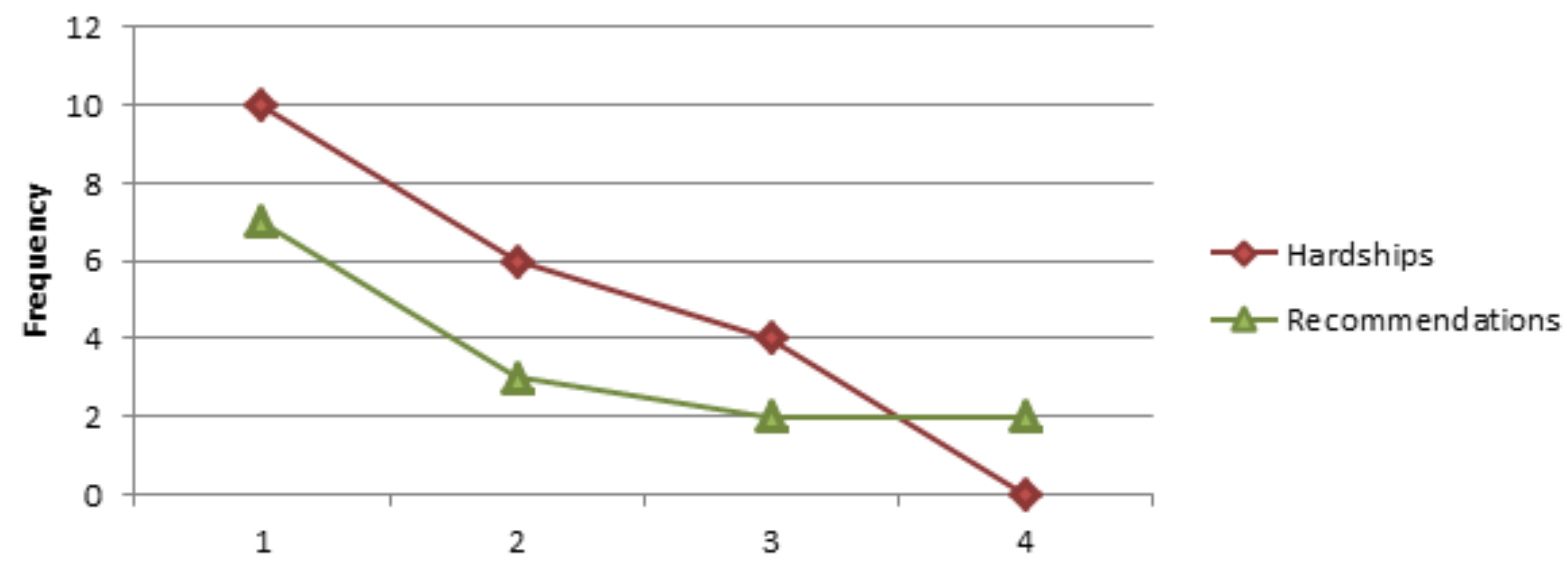

Fig. 11: Changes of Hardships and Recommendations According to the Process

Table 1:Comparison of the Needs Arising From the Teaching Curriculum Elements and Findings of Curriculum Evaluation Task

\begin{tabular}{lll}
\hline Curriculum Components & Needs Analysis Study Findings & Curriculum Evaluation Study Findings \\
\hline Objective & It should include gains at the level of knowledge and skill. & $\begin{array}{l}\text { Achieving objectives at the level of comprehension and } \\
\text { building skills }\end{array}$ \\
Content & $\begin{array}{l}\text { It should contain functional and professional life- } \\
\text { preparatory subjects }\end{array}$ & $\begin{array}{l}\text { Adequate content presentation } \\
\text { Topics preparing for professional life }\end{array}$ \\
$\begin{array}{l}\text { Learning-Teaching Process } \\
\text { (Educational Situations) }\end{array}$ & $\begin{array}{l}\text { Focusing on student interests, needs and requests, } \\
\text { Enabling authentic learning experience, } \\
\text { Making it easier to understand information, } \\
\text { Providing active participation }\end{array}$ & $\begin{array}{l}\text { Effective and efficient teaching } \\
\text { Processes and practices that support learning. } \\
\text { Planned and systematic teaching process }\end{array}$ \\
& $\begin{array}{l}\text { It must be of a quality that serves the permanence of } \\
\text { knowledge. }\end{array}$ & $\begin{array}{l}\text { Considering the basic principles of the assessment and } \\
\text { evaluation process }\end{array}$ \\
& $\begin{array}{l}\text { Measurement and evaluation tools with content validity } \\
\text { should be used }\end{array}$ & $\begin{array}{l}\text { Diversity in assessment and evaluation tools and } \\
\text { approaches }\end{array}$ \\
\hline
\end{tabular}


The information in Table 1 shows that the needs arising from the needs analysis study were largely met. Considering the categories and sub-categories of the components of the curriculum, it was found that outputs regarding understanding and skill were obtained, the content was sufficient and contained the subjects that prepared the pre-service teachers for professional life, the supportive understanding and practices in the teaching-learning process were effective, and these practices were organized in a planned and systematic, interesting and motivating manner. As for the assessment and evaluation process, it was reported that a variety of tools and approaches were used, and the basic principles were taken into consideration.

\section{Discussion}

When the findings obtained within the scope of the research were examined, it was seen that the first finding in relation with the components of the curriculum appears as "reaching the objectives with regards to understanding level and skill development." When the theoretical explanations regarding the curriculum development process are examined, it is understood that the curriculum components are interrelated in integrity, and a change in one of them affects the others (Oliva, 2005; Tyler, 2014). In this context, the quality of the objectives in pre-service teacher education curriculum can be said to directly affect the quality of the curricula. When teacher education curricula is examined in an international context, it is stated that most of these curricula focus on high-level thinking skills and the acquisition of professional knowledge and skills (Doğanay et al, 2015; OFSTED, 2014; TEAC, 2012).

Teaching is a profession that entails knowledge and skills. A qualified teacher is expected to have sufficient professional knowledge and skills (TCHE, 2018). This situation necessitates that the achievements in teacher education and the teaching process should be formed accordingly. The study findings meet the needs designated in the needs analysis and are thought to contribute to the quality of pre-service teaching curriculum.

Considering the codes that emerged regarding the content element of the curriculum, it was found that the content was sufficient and preparatory for professional life. As a matter of fact, the literature and needs analysis study were taken into consideration during the selection and editing of the content, and the subjects that were frequently emphasized and deemed necessary for the effective implementation of the combined class applications were included. In the literature, it is stated that in the selection and arrangement of the teaching content, it is necessary to benefit from the educational objectives determined on the basis of the realistic educational needs (Adıgüzel, 2016; Demirel, 2013; Oliva, 2005; Tyler, 2014; Wolf \& Hughes, 2007).

This situation gives the opportunity to analyze the problems, expectations, suggestions and level of knowledge of the target audience, and a more functional content can be created in line with this information obtained (Adıgüzel, 2016). The fact that the content of the course is stated according to the findings to be sufficient and prepared for professional life can be explained by the fact that the needs analysis study was carried out in a multi-dimensional way. Similarly, in a quasiexperimental study conducted by Sağ (2010), it was found that the effect of multigrade teaching course curriculum, which was designed based on problem and need-oriented experiences in pre-service teacher education, on pre-service teachers' selfefficacy scores was significantly higher. Emphasizing that the needs analysis studies are effective and helpful in determining the content of the units providing education services and in the smooth and appropriate transition between the contents (Karacaoğlu, 2012) supports both findings.

In terms of the teaching-learning process, the findings regarding the elements of the curricula show that the process was executed in an effective and efficient, planned and systematic, interesting and motivating manner. Doğanay and Sar1 (2009) stated that the first step to be taken for an effective education is good planning. It is thought that these perceptions of the participants about the teaching process stem from the "understanding and practices that support learning," emerging in this category. Considering the findings in the literature and theoretical explanations, benefitting from student-centered understanding and practices (Yalçın İncik \& Tanrıseven, 2012; Yeşilpınar Uyar, 2016); using different teaching methods and techniques in the process (Baştürk, 2011; İlter, 2014; Tan, 2010; Yeşilpınar Uyar, 2016); including audio-visual elements (Karakuş 2018; Kör, Çataloğlu \& Erbay, 2013; Uzunöz, Aktepe \& Gündüz, 2017); presenting authentic learning experiences (Arkün \& Aşkar, 2010; Sağ, 2010; Yeşilpınar Uyar, 2016); guiding learning (Cleaver \& Ballantyne, 2014; Cobb \& Steffe, 2011); making use of elaboration strategies and involving the learner in the teaching activities actively (Aremu \& Salami, 2013; Molina, Fernandez \& Nisbet, 2013; Ralph, 2014; Sağ, 2010; Yeşilpınar Uyar, 2016) are all seen to make the teachinglearning process effective, efficient and interesting. This situation also served in meeting the needs that arose in the needs analysis study.

When the findings obtained in the assessment-evaluation category are evaluated in a holistic manner, it is determined that the assessment-evaluation process was carried out with a student-centered approach, based on process evaluation, supporting thinking skills and individual development, enabling various tools and approaches and focusing on learning. This finding is thought to be in parallel with the findings in the teaching-learning process. Similarly, in the evaluation of a teaching process in which active participation and learning is carried out with a student-centered and lifebased approach, the student, learning process and learning products were taken into the center. In the literature, it is stated 
that the understanding that is effective in one component of the curricula should also be effective in others (Oliva, 2005; Tyler, 2014; Demirel, 2013), and if this is achieved, the functionality and effectiveness of the curricula will increase (Bümen, 2006; TCHE, 2010). It is thought that the functioning of the curriculum developed in practice creates a meaningful integrity in this respect.

The findings show that the curriculum contributed to the participants personally and professionally. Studies in the literature indicate that professional competence improves favorably in a process where active learning methods are implemented (Niemi \& Nevgi, 2014). The findings related to how the curriculum was implemented indicate that micro teaching helps a bridge be established between theory and practice, which may enable pre-service teachers to feel more competent in their profession. Besides, giving regular feedback to performances regarding in-class activities and micro teaching contributes to progress considerably. Bacevich (2010) notes the fact that the feedback given as a result of microteaching practices contributes to the development of preservice teachers in planning and implementation of teaching.

The findings regarding the evaluation of the curriculum show that there were some factors making teaching and learning difficult and some suggestions were addressed for a more efficient teaching. In this context, the participants considered the course's being taught in the senior year as a negativity and recommended that it should be given in the sophomore or junior term. The biggest reason underlying this negativity was the stress caused by the Public Personnel Selection Exam (PPSE) that pre-service teachers s are required to take at the end of the term. This problem has also been addressed in the related literature (Akpınar, 2013; Baştürk, 2011; Engin, Demirci \& Yeni, 2013). Stress is a factor that prevents learning, and it does not seem possible to create a flexible learning process in an environment where stressful individuals are present (Akpinar, 2013). In this sense, the participants emphasized that the course should be adjusted accordingly in the curriculum and taught in a different term because of this forementioned concern.

Anotherfinding wasthat the difficulties and recommendations of the participants decreased over time. Accordingly, it can be said that the needs of the participants were met to a large extent during the implementation of the curriculum.

\section{Conclusion and Suggestion}

When the findings regarding the components of the curriculum are evaluated in a holistic manner, it is seen that each category is the cause or the result of the other. For example, the fact that the participants stated that achievements at the level of comprehension and skill development were achieved can be explained by the existence of an understanding and practices that serve this in the teaching-learning and assessment and evaluation processes. Therefore, the curriculum designed for multigrade teaching course has been agreed to have met the needs to a large extent, contributed to students' personal and professional development and been feasible.

Considering the factors that make teaching and learning difficult, it was concluded that the final exam should be rearranged in terms of duration. However, considering the effect of having authentic experiences in the teaching process on achieving outcomes, it is thought that the opportunity to observe and practice in real classroom environments with different characteristics specific to multigrade classes (with one teacher, two teachers, three teachers, etc.) should be provided. The inclusion of the course in the last semester of the undergraduate curriculum caused the pre-service teachers preparing for PPSE to have problems in fulfilling the requirements of the course. In this context, it is thought that giving the course in the seventh term will increase the efficiency.

The curriculum examined in this study is a course already available in the Department of Primary School Teaching. The curriculum that emerged as a result of the study consisting of a researcher-practitioner, an observer and 34 pre-service teachers as a participant group, should be re-evaluated with a needs analysis study before being used in another context.

In this study, participatory evaluation approach was used in the evaluation of the curriculum. How the curriculum was implemented was evaluated in accordance with the data obtained from the student, the observer, and the researcherpractitioner. Research into the evaluation of the efficiency of the courses in teacher education curriculum can be repeated by using different evaluation approaches. The most difficult point in implementing the curriculum was that the preservice teachers had already been involved in the process of preparing for PPSE. This difficulty should be taken into consideration while carrying out longitudinal studies with a similar sampling.

\section{Limitation}

This research was carried out in the Department of Primary School Teaching, Faculty of Education, of a public university located in the east of the Mediterranean Region. The research is limited to 14 weeks ( 28 hours) of teaching within the scope of the Multigrade Classrooms Course in the spring term of the 2015-2016 academic year. In addition, the research is limited to a group of students studying in the Department of Primary School Teaching and taking the Teaching in Multigrade Classrooms Course, and the social context of the group included in the research.

\section{KaYNaKça}

$A^{\circ}$ berg-Bengtsson, L. (2009). The smaller the better? A review of research on small rural schools in Sweden. International Journal of Educational Research, 48(2), 100-108. 
Adıgüzel, O. C. (2016). Eğitim programlarının geliştirilmesinde ihtiyaç analizi el kitabı. Ankara: Anı Publishing.

Akpınar, B. (2013). Öğretmen adaylarının stres nedenleri. Kalem Eğitim ve İnsan Bilimleri Dergisi, 3(2), 147-174.

Aremu, A. \& Salami, I. A. (2013). Preparation of primary teachers in pupil-centred activity-based mathematics instructions and its model. European Scientific Journal, 9(19).

Arkün, S. \& Aşkar, P. (2010). Yapılandırmacı öğrenme ortamlarını değerlendirme ölçeğinin geliştirilmesi. Hacettepe Üniversitesi Ĕ̆itim Fakültesi Dergisi, 39(39), 32-43.

Arriaga, N. R., \& Ruiz-Gallardo, J. R. (2017). Colegios rurales agrupados y formación universitaria [Grouped rural schools and university education]. Profesorado, Revista de Currículum y Formación del Profesorado, 21(4), 215-240.

Bacevich, A. E. (2010). Building curriculum for teacher education: A study of video records of practice. Unpublished doctorate dissertation, University of Michigan, USA.

Bailey, K. D. (1982). Methods of social researches ( $2^{\text {nd }}$ Ed.). New York: The Free Press.

Baştürk, S. (2011). Matematik öğretmen adaylarının eğitim fakültesindeki eğitim-öğretim sürecini değerlendirmeleri. Uluslararası İnsan Bilimleri Dergisi, 8(1), 58-94.

Berry, C. \& Little, A., W. (2006). Multigrade teaching in London, in England. In A.W. Little (Ed), Education for all and multigrade teaching: Challenges and opportunities (pp. 67-86). Springer: Printed in the Netherlands.

Boix, R., \& Buscà, F. (2020). Competencias del profesorado de la escuela rural catalana para abordar la dimensión territorial en el aula multigrade [Catalan Rural Schools Teachers' Skills to Face the Territorial Dimension in the Multigrade Classroom]. Revista Iberoamericana Sobre Calidad, Eficacia y Cambio En Educación, 18(2), 115. Retrieved from https://doi.org/10.15366/ reice2020.18.2.006

Bua, J. D. \& Martin, M. D. M. (2020). Handling multi-grade teaching: It's educational implication towards teachers' competence. Management Research Journal, 9(2), 1-12.

Buaraphan, K., Inrit, B., \& Kochasila, W. (2018). Current policy and practice concerning multigrade teaching in Thailand. Kasetsart Journal of Social Sciences, 39(3), 496-501. Retrieved from https://doi.org/10.1016/j.kjss.2018.06.008

Burke, B. (1998). Evaluating for a change: Reflections on participatory methodology. New Directions for Evaluation, 80, 43-56.

Bümen, N. T. (2006). Üç büyük ildeki özel okullarda program geliştirme servislerinin etkililiği ve karşılaşılan problemler. Kuram ve Uygulamada Eğitim Bilimleri, 6(3), 615-667.

Chaparro-Aguado, F. \& Santos-Pastor, M. L. (2018). Competencias docentes para la escuela rural en la formación inicial, Análisis de resultados de un estudio multicaso [Teaching competences for the rural school in the initial training. Analysis of results of a multiple study]. Education, Sport, Health and Physical Activity, 2(2), 177-191.

Cleaver, D. \& Ballantyne, J. (2014). Teachers' views of constructivist theory: A qualitative study illuminating relationships between epistemological understanding and music teaching practice. International Journal of Music Education, 32(2), 228-241.

Creswell, J. W. (2016). Nitel araştırma yöntemleri beş yaklaşıma göre nitel araştırma ve araştırma deseni [Qualitative inquiry and research design: Choosing among five approaches]. M. Bütün \& S. B. Demir (Çev. Ed.). Ankara: Siyasal Publishing
Cobb, P. \& Steffe, L. P. (2011). The constructivist researcher as teacher and model builder. Journal for Research in Mathematics Education, 14(2), 19-30.

Cornish, L. (2006). What is multi-grade teaching? In L. Cornish (Ed.), Reaching EFA through multi-grade teaching (pp. 9-26). Armidale, Australia: Kardoorair Press.

Cousins, J. B., \& Whitmore, E. (1998). Framing participatory evaluation. New Directions for Evaluation, (80), 5-23.

Demirel, Ö. (2013). Eğitimde program geliştirme (19 ${ }^{\text {th }}$ Ed). Ankara: Pegem Akademi Yayıncılık.

Doğanay, A., \& Sarı, M. (2009). Öğretim amaçlarının belirlenmesi, ifade edilmesi ve uygun içeriğin seçimi. In A. Doğanay (Ed.), Öğretim ilke ve yöntemleri (s. 37-80). Ankara: Pegem Akademi Publishing.

Doğanay, A., Taş, M. A., Yeşilpınar, M., Yolcu, E., Türkkan Turhan, B., Sarı, M, Karakuş, M., Aybek, B., Sadık, F. \& Akbulut, T. (2015). Hizmet öncesi öğretmen eğitiminde model arayışı. International Journal of Curriculum and Instructional Studies, 5(9), 1-21.

Education Evaluation Report (Eğitim Değerlendirme Raporu [EER, EDR]), (2020). 2019 Eğitim değerlendirme raporu [Education evaluation report] (E. Karip (Ed). Ankara: Türk Eğitim Derneği. Retrieved from https://tedmem.org/download/2019egitim-degerlendirme-raporu? $\mathrm{wpdmdl}=3403 \& \mathrm{refresh}=6103 \mathrm{df}$ 757ea9f1627643765

Engin, A. O., Demirci, N., \& Yeni, E. (2013). Stres ve öğrenme arasındaki ilişki. Eğitim ve Öğretim Araştırmaları Dergisi, 2(2), 290-299.

Erdem, A.R. (2015). Birleştirilmişsınıflarda öğretim (7 $7^{\text {th }}$ Ed). Ankara: Anı Publishing.

Garaway, G. B. (1995). Participatory evaluation. Studies in Educational Evaluation, 21(1), 85-102.

Hardman, F., Stoff, C., Aung, W., \& Elliott, L. (2016). Developing pedagogical practices in Myanmar primary schools: Possibilities and constraints. Asia Pacific Journal of Education, 36(1), 98-118.

Hyry-Beihammer, E. K., \& Hascher, T. (2015). Multigrade teaching in primary education as a promising pedagogy for teacher education in Austria and Finland. Advances in Research on Teaching, 22C (Part C), 89-113. Retrieved from https://doi. org/10.1108/S1479-368720150000022005

İlter, İ. (2014). A study on the efficacy of project-based learning approach on Social Studies Education: Conceptual achievement and academic motivation. Educational Research and Reviews, 9(15), 487-497.

Jones, G. (2016). Alternative educators' perceptions of teaching multigrade classes and their views on students' social development. Unpublished doctoral thesis, USA: California State University. Retrieved from https://scholarworks.calstate. edu/downloads $/ 3 \times 816$ n792?locale $=$ en

Karacaoğlu, Ö. C. (2012). İhtiyaç analizi ve DACUM tekniği: Yayın editörlerinin eğitim ihtiyaçlarını belirleme örneği. Ankara Sağlık Bilimleri Dergisi, 1(1), 205-216.

Karakuş, U. (2018). Öğrenme-öğretme sürecinde materyallerin işlevi ve görsel materyallerin tasarımı. In A. Sezer (Ed.), Coğrafya öğretim teknolojileri ve materyal tasarımı (s. 55-72). Ankara: Pegem Akademi Publishing.

Marija R. Markovic; Anastasija S. Mamutovic; Zorica C. Stanisavljevic Petrovic. "Parents' attitudes towards children's adjustment to a pre-school institution". Journal for Educators, Teachers and Trainers, 10, 2, 2019, -. 
Kline, J., White, S., \& Lock, G. (2013). The rural practicum: preparing a quality teacher work- force for rural and regional Australia. Journal of Research in Rural Education, 28(3), 1-13. Retrieved from http://jrre.vmhost.psu.edu/wp-content/ uploads/2014/02/28-3.pdf

Korthagen, F. (2010). Situated learning theory and the pedagogy of teacher education: Towards an integrative view of teacher behavior and teacher learning. Teaching and Teacher Education, 26(1), 98-106.

Kör, H., Çataloğlu, E., \& Erbay, H. (2013). Uzaktan ve Örgün Eğitimin Öğrenci Başarısı Üzerine Etkisinin Araştırılması. Gaziantep University Journal of Social Sciences, 12(3), 267-279.

Landis, J. R., \& Koch, G. G. (1977). The measurement of observer agreement for categorical data. Biometrics, 33, 159-174.

Little, A. W., (1995). Multi-grade teaching: A review of research and practice. London: Department for International Development. Retrieved from https://files.eric.ed.gov/fulltext/ED459042.pdf

Little, A. W., (2001). Multigrade teaching: towards an international research and policy agenda. International Journal of Educational Development 21(6), 481-497.

Little, A. W., (2005). Learning and teaching in multigrade settings. Paper prepared for UNESCO 2005 EFA Monitoring Report.

Little, A. W., Pridmore, P., Bajracharya, H., \& Vithanapathirana, M. (2006). Learning and teaching in multigrade settings (LATIMS): A final report to DFID. Institute of Education, London. Retrieved from https://www.researchgate.net/ profile/Manjula-Vithanapathirana/publication/237472030_ Learning_and_Teaching_in_Multigrade_Settings_LATIMS_A_ final_report_to_DFID/links/02e7e527d96a92fabc000000/ Learning-and-Teaching-in-Multigrade-Settings-LATIMS-Afinal-report-to-DFID.pdf

Mason, D., A. \& Burns, R. B. (1997). Reassessing the effects of combination classes. Educational Research and Evaluation, 3(1), 1-53.

McCain, D.V. (2005). Evaluation basics. Alexandria: American Society for Training \& Development.

Merriam, S. (2013). Assessing and evaluating qualitative research. In S. Merriam (Ed.), Qualitative research in practice: Examples for discussion and analysis (pp.18-36). San Francisco: Jossey-Bass.

Miles, M. B. \& Huberman, A. M. (1994). Data management and analysis methods. In N. K. Denzin, \& Y. S. Lincoln (Eds.), Handbook of Qualitative Research (pp. 428-444). Sage, Thousand Oaks.

Miller, B. A. (1991). A review of the qualitative research on multigrade instruction. In: Reaching Our Potential: Rural Education in the 90's. Paper presented at the Rural Education Symposium, Nashville, TN. Retrieved from https://files.eric.ed.gov/fulltext/ ED342563.pdf

Molina, R., Fernandez, M. L., \& Nisbet, L. (2011). Analyzing elementary preservice teachers' development of content and pedagogical content knowledge in mathematics through microteaching lesson study. In M. S. Plakhotnik, S. M. Nielsen, \& D. M. Pane (Eds.), Proceedings of the Tenth Annual College of Education \& GSN Research Conference (pp. 162-168). Miami: Florida International University. Retrieved from https:// digitalcommons.fiu.edu/cgi/viewcontent.cgi?article $=1181 \& \mathrm{c}$ ontext=sferc

MoNE (The Ministry of National Education [Milli Eğitim Bakanlığı, MEB]), (2005). Milli eğitim istatistikleri 2004-2005.
Ankara: Araştırma, Planlama ve Koordinasyon Kurulu Başkanlığı Devlet Kitapları Müdürlüğü Basımevi.

MoNE (The Ministry of National Education [Milli Eğitim Bakanlığı, MEB]), (2020). Milli eğitim istatistikleri: Örgün eğitim. Ankara: Milli Eğitim Bakanlığı Strateji Geliştirme Başkanlığ 1 . Retrieved from https://sgb.meb.gov.tr/meb_ iys_dosyalar/2020_09/04144812_meb_istatistikleri_orgun_ egitim_2019_2020.pdf

Mortazavizadeh, S. H., Nili, M. R., Isfahani, A. R. N., \& Hassani, M. (2017). Teachers' lived experiences about teaching-learning process in multi-grade classes. Journal of Education and Learning, 6(4), 354-363.

Mulryan-Kyne, C. (2007). The preparation of teachers for multigrade teaching. Teaching and Teacher Education, 23(4), 501-514.

National Teacher Strategic Document (NTSD, [Ulusal Öğretmen Stratejisi Çalıştayı]), (2011). Uyum ve Adaylık Süreci, Sürekli Mesleki Gelişim Çalışma Grubu Raporu. Yayımlanmamış çalıştay raporu. Retrieved from http://www.memurlar.net/ common/news/documents/373146/ulusal_ogretmenlik_ strateji_taslak.pdf

Niemi, H., \& Nevgi, A. (2014). Research studies and active learning promoting professional competences in Finnish teacher education. Teaching and Teacher Education, 43, 131-142.

O'Connor, C., \& Joffe, H. (2020). Intercoder reliability in qualitative research: Debates and practical guidelines. International Journal of Qualitative Methods, 19, 1-13. https://doi. org/10.1177/1609406919899220

OFSTED (Office for Standards in Education, Children's Services and Skills). (2014). Initial teacher education inspection handbook. Retrieved from www.ofsted.gov.uk

Oliva, P. F. (2005). Developing the curriculum. New York: Allyn and Bacon.

Oral, I. \& McGivney, J., E. (2014). Türkiye eğitim sisteminde eşitlik ve akademik başarı araştırma raporu ve analiz. Retrieved from http://erg.sabanciuniv.edu/sites/erg.sabanciuniv.edu/files/ ERGe\%C5\%9FitlikWEB.22.05.14.pdf

Pavan, N., B. (1992). The benefits of nongraded schools. Educational Leadership, 50(2), 22-25. Retrieved from http://www.ascd.org/ publications/educational-leadership/oct92/vol50/num02/TheBenefits-of-Nongraded-Schools.aspx

Patton, M. Q. (2002). Qualitative evaluation and research methods ( $3^{\text {rd }}$ ed.). London: Sage Publications.

Pratt, D. (1986). On the merits of multiage classrooms. Research in Rural Education, 3(3), 1. Retrieved from http://citeseerx.ist.psu. edu/viewdoc/download?doi=10.1.1.517.701\&rep=rep1\&type $=$ pdf

Ralph, E. G. (2014). The effectiveness of microteaching: Five years' findings. International Journal of Humanities, Social Sciences and Education (IJHSSE), 1, 17-28.

Raso, F., Hinojo, M. A., \& Solá, J. M. (2015). Integración y uso docente de las tecnologías de la información y la comunicación (TIC) en la escuela rural de la provincia de Granada: estudio descriptive [Introduction and teaching use of information and communication technologies (ICT) in Grenadian rural schools (Spain): Descriptive study]. Revista Iberoamericana sobre Calidad, Eficacia y Cambio en Educación, 13(1), 139-159.

Sağ, R. (2010). Etkinlik teorisine göre zenginleştirilmiş birleştirilmiş sınıflarda öğretim uygulamalarının öğretmen adaylarının özyeterlik algılarına etkisi. Eğitim ve Bilim Dergisi, 35(158), 44-57. 
Sağ, R. (2011). Birleştirişmiş sınıf öğretmeni olmaya yönelik öz-yeterlik ölçeği geliştirilmesi. Hacette Üniversitesi Ĕ̆itim Fakültesi Dergisi, 41, 386-397.

Sanders, J. R. \& Nafziger, D. H. (1976). A basis for determining the adequacy of evaluation designs. Occasional Paper 6. Kalamazoo: Western Michigan University Evaluation Center.

Suwanrat, O. (2012). The school administration for multigrade teaching in small schools: A case study of Ban Kok Chareon school, Phang Nga province. Phang Nga, Thailand: Ban Kok Chareon school. [in Thai]

Tan, Ş. (2010). Öğretim ilke ve yöntemleri dersinde öğrencilerin akademik başarılarının yordanması. Uludă̆ Üniversitesi Eğitim Fakültesi Dergisi, 23(1), 239-266.

TCHE (The Council of Higher Education [Yükseköğretim Kurulu, YÖK]), (2007). Eğitim fakültesi öğretmen yetiştirme lisans programları. Retrieved from https://www.yok.gov.tr/ Documents/Yayinlar/Yayinlarimiz/egitim-fakultesi-ogretmenyetistirme-lisans-programlari.pdf

TCHE (The Council of Higher Education [Yükseköğretim Kurulu, YÖK]), (2010). Türkiye yükseköğretim yeterlilikler çerçevesi (TYYÇ). Retrieved from http://tyyc.yok.gov.tr/?pid=20

TCHE (The Council of Higher Education [Yükseköğretim Kurulu, YÖK]), (2018). Öğretmen yetiştirme lisans programları. Ankara: Yükseköğretim Kurulu Başkanlığı. Retrieved from http://www. yok.gov.tr/documents/10279/41805112/AA_Sunus_+Onsoz_ Uygulama_Yonergesi.pdf

TEAC (Teacher Education Accreditation Council) (2012). Guide to accreditation: Accreditation of teacher education through the audit of evidence of student achievement. Retrieved from http://www.teac.org.

Thomas, C \& Shaw, C. (1992) Issues in the development of multigrade schools. World Bank Technical Paper 172. The World Bank, Washington, DC. Retrieved from http://www-wds.worldbank. org/servlet/WDSContentServer/WDSP/IB/1999/10/21/000178 830_98101904141971/Rendered/PDF/multi_page.pdf
Tyler, R. W. (2014). Eğitim programlarının ve öğretimin temel ilkeleri (Rüzgar M. E. \& Aslan, B. Çev.). Ankara: Pegem Akademi Yayıncilık.

UNESCO, (1989). Multigrade teaching in single teacher primary schools. Bangkok: Principal Regional Office for Asia and the Pacific.

Uzunöz, A., Aktepe, V., \& Gündüz, M. (2017). Öğretim teknolojileri ve materyal tasarımı dersinin, mesleki açıdan kazandırdıklarına ilişkin öğretmen adaylarının görüşleri: Nitel bir çalışma. Eğitimde Nitel Araştırmalar Dergisi, 5(3), 317-339.

Veenman, S. (1995). Cognitive and noncognitive effects of multigrade and multi-age classes: a best-evidence synthesis. Retrieved from www.multiagelearninglabs.com/Research/Cognitive $\% 20$ and $\% 20$ noncognitive $\% 20$ effects $\% 20$ of $\% 20$ multigrade $\% 20$ and $\% 20$ multi.doc.

Wenger, K. J. \& Dinsmore, J. (2005). Preparing rural preservice teachers for diversity. Journal of Research in Rural Education (2).

Wolf, P. \& Hughes, J., C. (2007). Yükseköğretim eğitim program geliştirme. Öğretim üyeleri tarafından yürütülen süreçler ve uygulamalar [Curriculum development in higher education, New directions for teaching \& learning]. M.T. Atay (Cev. Ed.) Ankara: Edge ve Elhan Kitap Yayın Dağıtım.

Yalçin İncik, E., \& Tanrıseven, I. (2012). Eğitim Fakültesi Öğretim Elemanlarının ve Öğretmen Adaylarının Öğrenci Merkezli Eğitime İlişkin Görüşleri (Mersin Üniversitesi Örneği). Mersin Üniversitesi Eğitim Fakültesi Dergisi, 8(3), 172-184.

Yeşilpınar Uyar, M. (2016). Öğretim ilke ve yöntemleri dersine yönelik okul temelli bir öğretim programı geliştirme çalışması. Unpublished doctorate dissertation, Çukurova University, Turkey.

Yıldırım, A., \& Şimşek, H. (2013). Sosyal bilimlerde nitel araştırma yöntemleri. Ankara: Seçkin Yayıncılık.

Yin, R. K. (2003). Case study research: Design and methods (3rd ed.). Sage Publications.

Zukoski, A., \& Luluquisen, M. (2002). Participatory evaluation: What is it? Why do it? What are the challenges. Policy and Practice, 5, 3-8. 